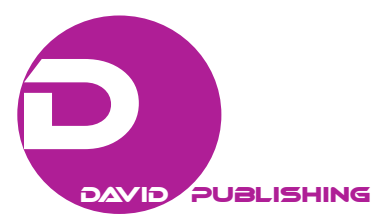

\title{
Economic Violence: Which Economy Law Instruments Are More Effective*
}

\author{
Eugenio Maria Mastropaolo \\ Università Telematica Pegaso, Naples, Italy
}

\begin{abstract}
The Council of Europe Convention on 11 May 2011 addresses the economic violence as one kind of violence a woman may face when dealing with income from work, access to the labor market, establishment of enterprises, access to entrepreneurial activities and governance bodies. The paper focuses on four typical situations of economic violence and subsequent risks for the woman and society and economy. Economy law may propose the use of instruments to prevent or fight economic violence: from tax incentives, to women's enterprise incentives; from direct finance, to loans at discounted rates; from gender quotas to incentives to build educational and professional skills dedicated to women in order to fill the gap and even the playing field. Some of them have been already used successfully, others not so, but their common element is that there is a better and specific educational and training need for women to prevent economic violence. The paper will discuss data with respect to certain instruments within the Italian legal framework. The paper will address needs for better and specific education and training before introducing new economy law measures in the Italian legal framework, pursuant in some cases to EU legislation.
\end{abstract}

Keywords: economic violence, economy law instruments, entrepreneurial woman skills, woman education and training needs

\section{Economic Violence and Impact on Woman and the Society}

\section{Legal Framework, Definition, and Classification of Economic Violence}

The Council of Europe Convention on preventing and combating violence against women and domestic violence of 11 May 2011 (the "Istanbul Conference") addresses the economic violence as one kind of violence a woman may face.

Economic violence may be defined as the violence which women may face when dealing with income from work, access to labor market, establishment of business, access to entrepreneurial activities and governance bodies or leading positions in business.

Economic violence can be classified as a second tier violence against women, within two different meanings: (i) Although it is not a direct violence, physically hurting a woman, economic violence hinders a

\footnotetext{
* Acknowledgement: The author would like to thank Mrs. Rosa Salvati of Università Telematica Pegaso, Naples, Italy for the precious help in finding data.

Eugenio Maria Mastropaolo, prof. avv., lawyer admitted to Rome Bar; professor of Economy Law and Banking Law, Law Faculty, Università Telematica Pegaso, Naples, Italy.

Correspondence concerning this article should be addressed to Eugenio Maria Mastropaolo, @ Studio Gitti, Via Dante 9, Milan 20123, Italy.
} 
woman to make decisions freely on whether or not leave a situation where she is at risk of additional injuries, or worse being killed; (ii) economic violence may be considered on the other hand as a preliminary violence to psychologically justify subsequent violence and finally compress woman to make decisions freely about her professional life, which may lead to the difficulty or impossibility in the situation described above under (i) to leave it.

In this sense, economic violence is subtle and, due to profitable cultural environments to woman economic discrimination, it is not easily perceived or at least distinguished from other kinds of violence. Worse, economic violence is a kind of permanent violence which once started always leads to a bad situation. Each discrimination, each gesture of economic violence, adds a single brick to the complex situation, preparing a fruitful ground for the next episode of economic violence or other kind of more serious violence.

\section{Impact on Woman}

As mentioned above economic violence generates two kinds of risks for a woman.

A woman who is subject to economic violence faces (i) the risk of being regarded as a "minus" if compared with men and consequently poor self-esteem, which leads to undeveloped skills, laying the ground work for other kinds of violence and (ii) the risk of not having any choice other than remaining in the violent situation, at risk of being harmed, badly injured, or even killed.

If we focus on "poor self-esteem" the consequence is not only psychological (which per se is highly negative) but also leads a woman to under-develop her own skills, to avoid pursuing her dreams or happiness, to give up what should be reasonably attained based on her education level and in line with expected professional growth.

\section{Impact on Society}

For any society, economic violence is a pure loss.

Women's contribution to the growth of a better and peaceful society is fundamental.

Work and business relationships are better once they involve women who more easily and practically find reasonable solutions to the most disruptive situations where normally men would fight and take useless risks.

As we would point out below, women are less likely to be risk takers than men and are less keen to align themselves to groupthink. Although this approach may seem to be based on stereotypes, it is the same approach that has been taken by European Banking Authority and European Securities and Markets Authority in a formal document addressed to European Union banks (see below).

But the impact on the society is not limited to the above. There is a certain kind of systemic risk in economic violence. If perpetrated at a single level, it gives ground and it may seem possible for it to be perpetrated towards more women. Furthermore, even if not directly hampered, women start behaving as if they were victims of such violence, renouncing their rights.

\section{Impact on the Economy}

From society to economy the step is very close.

Women's contribution is necessary for a growing and sustainable economy. Such contribution must be equal to the contribution of men in terms of quality and quantity.

But the impact of economic violence may hamper such contribution.

Firstly: Economic violence is a loss of financial resources for growing economies as well as mature economies. Educational costs. If a well-educated woman faces difficulties in finding a job or has to fight 
against discrimination, culturally based stereotypes and unfit business organizational structures and fully or partially gives up, this will be a loss of finance resources because money spent for her education will not be recovered by ordinary and progressive taxation on her revenues, which by the way finances education for future generations.

Secondly: Economic violence can be regarded as a loss of opportunity. Hampered through economic violence, female participation in the economic process in terms of not working, working as a non-skilled or poorly-skilled employee (these employees are more at risk of unemployment due to changes in the labor market and in industrial and commercial production and distribution processes), working in a job position which is personally perceived as unsuitable or which is perceived as the consequence of discrimination, generates economic damage in terms of frustrated employees which, in turn, slows working process, and adds to the loss of exploitable blue ocean economic ideas (through the establishment of start-up and new businesses or new products and services design) and loss of the opportunity to change mentality in and approach to production and distribution processes.

\section{Economic Violence Schemes}

We have found four different economic violence schemes.

\section{First Scheme-Working Denial}

The first scheme is quite simple and common. The woman's male partners or the woman's original family deny or suggest that she avoid working on the basis that she has to take care of children or other family members or they suggest that professional activities will be overly time consuming with respect to family activities, such as housework.

This appears more as a psychological violence, conditioning her will and weakening her possibilities in the future from a professional point of view. Normally these women end, before completion, their secondary educational process or fail to complete any kind of educational process, but this is not suitable for finding satisfactory work and often the ultimately give-up.

\section{Second Scheme—Revenues or Assets Seized}

The second scheme is more complex and violent. In this case, the woman's male partner or males in her original family (normally the father or a brother) seizes incomes gained by the woman or obliges the woman to work for free in a family enterprise (in such cases revenues for the woman's work are not paid and the example must be turned to monies that she would have gained if she were employed out of the family context).

This kind of economic violence is more visible when the woman involved has no or poor access to financial resources or this access is not proportional to the quantity or quality of her work or is conditional on the willingness of her partner or the original family (i.e., the woman receives a certain sum of money, but this appears more as a "gift" than a salary). In all the above situations the woman has no evidence of the financial situation of her family and the money received is only granted for basic and specific needs, hampering any possibility of savings for future expenses or other expenses such as leisure or cultural ones.

Sometimes this kind of violence has a legal impact as the woman is requested to issue personal guarantees on her personal assets for the benefit of lending entities and in the interest of the family business or the partner (in this case the woman faces the risk of being deprived of her assets as a consequence of lender actions) or worse the woman is formally appointed as the entrepreneur but in fact she is only a figurehead. 


\section{Third Scheme-Heredity of the Family Business}

In the third scheme although the woman has proper skills and aptitude to run the family business as an heir or potential heir, she has been convinced to build her educational career in a manner that she will be discriminated in the succession or, notwithstanding, even if she may be fit to take an executive role within the business, male family members are preferred.

Again, as in the second scheme, this economical violence does not emerge in one single episode, but grows little by little and finally at the end seems the unavoidable and reasonable consequence. It may even be as such, if one looks only at the end of the story but it would not be unavoidable if the woman involved was properly educated and involved in the family business from the beginning. But even proper education and knowledge of the family business sometimes are not considered enough to run it at the time of generational change, as men are preferred to women. In certain situations the preferred man is the woman's partner who then becomes an executive and takes an important role in lieu of the woman, which per se it is not bad, as there are many successful examples of this situation, but there are as well examples of men who wasted assets inherited by their female partners.

\section{Fourth Scheme-Access to Governance Bodies and Executive Roles}

The woman has high relationship, educational and professional skills but has poor access to company governance bodies and in particular to executive roles.

Although this is not perceived as a form of economic violence, this form of discrimination can be brought back to the broad definition of it, as it involves economic factors such as business, enterprises, companies ... decision making, and executive roles.

Because this kind of economic violence involves woman with high education and professional skills, it is more addressed and contrasted by legal measures and at a cultural level context, although results at least in Italy, are long to come, if we move from top companies to medium-large companies.

\section{Economy Law Instruments}

\section{Economy Law Scope in Italy}

Economy law under Italian legislation and, in particular, under the scope defined by the Minister of Education, University and Scientific Research, is the legal discipline which studies public intervention legislation over production of goods and services and with particular focus on financial aspects of business. In broader terms, the scope of economy law, in Italian legal theory and system, covers some aspects of taxation or direct public intervention in the economy; banking, finance and insurance business from a contractual law perspective, governance and organization as well as the supervisory authority intervention for prudential supervision; consumer protection; other businesses supervised by independent authorities; company governance and organization.

If one looks to Italian economy law, its contribution to prevent and fight economic violence may be deemed unimpressive if compared to labor law or criminal law.

However, because economy law deals with financial aspects of business and legal and economic instruments which can be classified under its scope, it may be used to prevent economic violence.

\section{Italian Economy Law Instruments Promoting Female Entrepreneurship}

Legal measures. Italian economy law's main piece of legislation is represented by Law No. 215 of 25 
February 1992. Law 215/1992 proposes the use of legal and economic instruments to promote the role of women in the economy and as such, although not expressly stated in the law, to prevent or fight economic violence.

The first group of measures are directly co-financing by the state at $50 \%$ without obligation for reimbursement for small/medium enterprises (defined as enterprises with less than 50 employees, less than $€ 7$ mln. of annual turnover and less than $€ 5 \mathrm{mln}$. of total assets): (i) if they are represented by a single entrepreneur, the entrepreneur must be a woman; (ii) if they are represented by an unlimited liability partnership or cooperatives at least the $60 \%$ of stakeholders or quota holders must be women and involved in company management; (iii) if they are represented by limited liability companies, partnerships or joint-stock companies, $2 / 3$ of paid-in capital must at least be held by women and at least $2 / 3$ of the board of directors must be comprised by women. These companies must invest in industry, commerce, handcraft, agriculture, services, and tourism. Financing may go to start-ups or to acquire existing businesses and innovative projects. Women must not be employees of any company participating in the financed company or enterprise capital. The remaining part of the expenditure may be financed by authorized lenders (banks and financial institutions) at a facilitated fixed interest rate lower than the market interest rate. The spread between the two rates is covered by the state.

Another group of measures are directed to promote "smart \& start" women's enterprises in the south of Italy (a zone with the lowest Italian GDP pro capite). Smart because the enterprise must promote new business models in terms of organization and production, in this sense they innovate old-fashion business models. Start because the enterprise must be a start-up in the digital economy or scientific research. Again, these kinds of enterprises are co-financed by the State.

The third group of measures is tax incentives to enterprises established by women, which may concur with the previous measures.

It is worth noting that the above are measures only at a state level, as each Italian region may establish local measures in order to promote female enterprises.

Establishing success rate measures. In general, public available data show ${ }^{1}$ that growth of women-led enterprises is faster than the growth of overall enterprises $(+4.1 \%, 2014 / 2016$ when compared to 2012/2014 for female enterprises vs. $+2.1 \%)$.

Women-led enterprises in 2016 represent $21.8 \%$ of the total number of enterprises. More women are joining together to run businesses as cooperatives companies ( $1 / 3$ of the total number of cooperatives are run by women). Tourism sector is most impacted: $29.7 \%$ are woman enterprises and the growth of women-led enterprises in this industry exceeds the average growth by $0.7 \%$. If we limit the analysis to lodging and hospitality run by people under 35 years old, in 2016, 34.5\% are women-led enterprises.

What is not available is the failure rate of these enterprises. Enterprise creation and failure rate is calculated by each Italian province's Chamber of Commerce enterprise register; however this statistic gives only the balance between new and failed enterprises. To assess if enterprises run by women have been more successful than enterprises run by men, or better to assess if incentives were properly granted, it would be interesting to have the following statistics: at 1, 5, and 10 years from creation how many enterprises are still up and running by the founding woman.

\footnotetext{
${ }^{1}$ Unioncamere, 2016 Report on "Imprenditoria femminile nel turismo", 27 October 2017; Censis-ConfCommercio, 2014-2016 Report on "Donne al lavoro, la scelta di fare impresa".
} 


\section{Italian Economy Law Instruments Promoting the Presence of Women in Governance Bodies}

Italian law measures. More interesting are economy law instruments obliging joint-stock companies per shares listed in Italian regulated markets, authorized pursuant to Italian Legislative Decree No. 58 of 24 February 1998 as amended from time to time and lastly transposing EU Directive 2014/64 of the European Parliament and of the Council of 15 May 2014 (so-called and hereinafter MiFID2), to grant a quota of at least $1 / 3$ of places in governance bodies to the underrepresented gender (normally women) (Law No. 120 of 12 July 2011) or providing that EU banks shall promote diversity and inclusion, with particular reference to underrepresented gender (see Article 88(2), letter (a) of EU Directive 2013/36 of the European Parliament and of the Council of 26 June 2013, so-called and hereinafter CRD IV) to achieve prudential supervision targets. Although application of such an EU measure is not compulsory and at the moment Italy has not enacted special legislation on this topic, it is interesting to understand the rationale, scope and potential consequences of the application of the EU measure.

EU Banking measures to be transposed into Italian Law. CRD IV provides that major banks must appoint within the board of directors a special committee that evaluates candidates suitable for executive and non-executive roles. The nomination committee "shall decide on a target for the representation of the underrepresented gender in the management body and prepare a policy on how to increase the number of the underrepresented gender in the management body in order to meet that target. The target, policy and its implementation shall be made public in accordance with Article 435(2) (c) of Regulation (EU) No. 575/2013".

However more interesting is "whereas" to CRD IV No. 60,

The lack of monitoring by management bodies of management decisions is partly due to the phenomenon of "groupthink". This phenomenon is, inter alia, caused by a lack of diversity in the composition of management bodies. To facilitate independent opinions and critical challenge, management bodies of institutions should therefore be sufficiently diverse with regard to age, gender, geographical provenance and educational and professional background to present a variety of views and experiences. Gender balance is of particular importance to ensure adequate representation of population. In particular, institutions not meeting a threshold for representation of the underrepresented gender should take appropriate action as a matter of priority ... More diverse management bodies should more effectively monitor management and therefore contribute to improved risk oversight and resilience of institutions. Therefore, diversity should be one of the criteria for the composition of management bodies. Diversity should also be addressed in institutions' recruitment policy more generally. Such a policy should, for instance, encourage institutions to select candidates from shortlists including both genders.

The European Banking Authority together with the European Securities and Markets Authority implementing "Whereas" No. 60 to CRD IV issued "Joint Guidelines Implementing CRD IV and MiFID2" (2017) of 26 September 2017 entering into force on 30 June 2018 and currently under Italian Minister of Economy and Finance transposition. Paragraph No. 3 and preparation works identify as one of the reasons of the 2008 banking sector crisis weakness of bank governance bodies due to lack of diversity and the lack of independence of mind. Therefore the need to have diversity in board of directors and executive roles as well as for "management and supervisory functions where a sufficiently large management body exists" and controlling functions, provided that for small entities the target may be reached through quality instead of quantity (i.e., one experienced woman against more women with less experience in the management body) (Paragraph No 105) "to achieve a variety of views and experiences and to facilitate independent opinions and sound decision-making within the management body" (Paragraph No. 104) which has been defined as "Independence of mind", a psychological behavior that allows a person with 
Courage, conviction and strength effectively assess and challenge the proposed decisions of other members of the management body; being able to ask questions to the members of the management body in its management function; and being able to resist <group-think>. (Paragraph No. 82)

Establishing success rate measures. EU Banking measures are too young to be evaluated. However, there are strong expectations regarding the implementation of such measures.

Law 120/2011's application is monitored by the Italian Securities and Exchange Commission (CONSOB). The 2016 Annual Report (http://www.consob.it/web/area-pubblica/relazione-annuale) of 8 May 2017 shows that the $1 / 3$ of the target has been reached in 2016 (31.6\% of the number of directors corresponding to 701 woman), with 226 listed companies with at least one woman on the board (cover ratio of $99.1 \%$ of overall listed companies).

Based on 2015 data, the educational level is high, $88.9 \%$ of women held a university degree vs. men at $84.5 \%$; post graduate (master or Ph.D.) levels were $29.7 \%$ vs. $16.7 \%$, respectively, with an average age of 50.9 years old for women and 58.9 for men. Female directors have more a professional and academic background than a managing background (respectively $33.2 \%$ vs. $16.6 \%$ for professionals; $12.2 \%$ vs. $6.4 \%$ for academics; $54.1 \%$ vs. $76.5 \%$ for managers; $0.5 \%$ each for other. Very interesting is the rate of family links with controlling shareholders (directors could also be the controlling shareholder): $13.1 \%$ of family-linked women vs. $16.9 \%$ of men.

Based again on 2016 data there is a growth of interlocking ratio for women (i.e., the same director member of one or more listed company boards or board of statutory auditors) as pointed out by Assonime, the association of listed companies ("Assonime 2017 Report", 2018). It means that listed companies prefer to have in their board of directors more experienced women, member of other listed companies board of directors. But it could also mean that unless a growing request, there is a lack of women who are willing to be involved or who lack proper skills.

\section{Conclusions: Fostering Effectiveness of Economy Law Instruments to Stop Economic Violence Towards Woman}

The overall picture of Italian economy law instruments which may be used to stop economic violence is good.

All instruments may be employed and may be requested by women to remove themselves from dangerous situations as well as promote themselves as entrepreneurs.

However, companies and enterprises are small and the risk is that although they received direct or tax incentives they are unable to survive weather a market crisis may arise.

There is a lack of educational opportunities exclusively dedicated to women who may wish to become entrepreneurs and therefore do not fall under the four risk scenarios.

Based on temporary results in field research, secondary school girls lack knowledge about their rights within special legislation aiming to improve female participation in the economy, in governance bodies, and therefore are unable to properly build their $\mathrm{CV}$ due to this.

The lack of better and specific education and training is more evident if one looks at the legislation granting quotas to the underrepresented gender (i.e., women) as more women managers are needed in order to balance the proportions with male managers.

This gap will be more evident once gender diversity obligations become effective for boards of directors, managing and supervisory bodies, and functions that are applicable to any supervised banking and investment 
firm entity (more or less 1,000 entities in Italy).

Therefore, in order to foster effectiveness in economy law measures to contribute to the prevention of economic violence against women, quick and high level investments must go in the direction of increasing the managerial skills of women through proper executive business administration education.

\section{References}

$\begin{array}{llll}\text { Assonime } & 2017 & \text { report. } & \text { (2018). }\end{array}$ http://www.assonime.it/_layouts/15/Assonime.CustomAction/GetPdfToUrl.aspx?PathPdf=http://www.assonime.it/attivita-ed itoriale/studi/Documents/Note\%20e\%20Studi\%202\%202018.pdf

Joint guidelines implementing CRD IV and MiFID2. (2017). Retrieved from https://www.eba.europa.eu/documents/10180/1972984/Joint+ESMA+and+EBA+Guidelines+on+the+assessment+of+suitabil ity+of+members+of+the+management+body+and+key+function+holders+\%28EBA-GL-2017-12\%29.pdf 